\title{
Effect of Graded Dietary Levels of Tree Leaf Meal on Growth Performance and Carcass Characteristics of Japanese Quails
}

\author{
Karu. Pasupathi*, C. Valli, S. Gunesekaran, V. S. Mynavathi, \\ M. Manobhavan and S. T. Selvan \\ Post Graduate Research Institute in Animal Sciences, Kattupakkam \\ Tamil Nadu Veterinary and Animal Sciences University, India \\ *Corresponding author
}

\begin{abstract}
A B S T R A C T
Keywords

Japanese Quails, Gliricidia sepium,

Tree Leaf Meal

Article Info

Accepted:

11 June 2020

Available Online:

10 July 2020

A trail was conducted to assess the growth performance of quails with the tree leaf meal prepared using leaves pruned from Gliricidia sepium in silvipasture. 250 Nos. of quails were randomly divided into five treatment groups, 50 quails in each treatment. Group-1 fed with control diet without tree fodder, group-2, 3, 4 and 5 were fed with tree fodder included diet @ $0.25,0.50,0.75$ and 1.00 per cent level. There is no significant difference was observed on the growth performance among the treatment groups. Hence, Gliricidia sepium tree leaf meals can be safely included up to1.0 per cent in the ration to reduce the cost of production without affecting the growth performance.
\end{abstract}

\section{Introduction}

Feed cost is the major expenditure in Quail farming. Among the nutrients, the cost involved for protein seems to be higher than other nutrients. Reducing the protein cost eventually leads to minimize the production cost. Hence, to study the cheaper source of protein, the tree leaf meal prepared using leaves pruned from Gliricidia sepium in silvipasture, a trial was conducted to assess the growth performance on Japanese Quails.
250 Nos. of quails were randomly divided into five treatment groups, 50 quails in each treatment. Group-1 fed with control diet without tree fodder, group-2, 3, 4 and 5 were fed with tree fodder included diet @ 0.25, $0.50,0.75$ and 1.00 per cent level. There is no significant difference was observed on the growth performance among the treatment groups. Hence, Gliricidia sepium tree leaf meals can be safely included up to1.0 per cent in the ration to reduce the cost of production without affecting the growth performance. 


\section{Materials and Methods}

Japanese Quails available in the Poultry Unit of Post Graduate Research Institute in Animal Sciences, Kattupakkam were utilized for this study. 250 Nos. of quails were randomly divided into five treatment groups, 50 quails in each treatment. Group-1 fed with control diet without tree fodder, group-2, 3, 4 and 5 were fed with tree fodder included diet @ $0.25,0.50,0.75$ and 1.00 per cent level.

Feed offered and residue leftover were weighed and recorded daily. All the quails were weighed at weekly intervals up to $6^{\text {th }}$ week. 10 birds from each treatment were slaughtered to study the carcass characteristics. All the data collected were analysed statistically as per Snedecor and Cochran (1990) using IBM SPSS 20.

\section{Results and Discussion}

The growth performances of Japanese quails were comparable in all Gliricidia sepium leaf meal included diet with the control diet. The average daily gain per bird was did not vary significantly across treatments and it was $4.78,5.09,4.77,4.89$ and $4.99 \mathrm{~g}$ per day, respectively in $0.00,0.25,0.50,0.75$ and 1.00 per cent Gliricidia sepium leaf meal included rations. Mahmud et al., (2015) reported that replacing maize up to 15 per cent level with neem leaf meal did not affect the growth performance in Japanese Quails.

This study is contradict to the earlier findings of Kout Elkloub et al., (2015) who conducted trial with Moringa leaf meal in quails and found that improved growth performance and FCR in quails.

Table.1

\begin{tabular}{|c|c|c|c|c|c|}
\hline Week & T1 (0\%) & $\mathrm{T} 2(0.25 \%)$ & T3 (0.50\%) & T4 (0.75\%) & T5 $(1.00 \%)$ \\
\hline $\begin{array}{l}\text { Day old chick } \\
\text { weight (g) }\end{array}$ & $8.94 \pm 0.13$ & $9.07 \pm 0.12$ & $9.18 \pm 0.11$ & $8.86 \pm 0.12$ & $9.07 \pm 0.12$ \\
\hline $\begin{array}{l}\text { Final weight on } \\
\text { VI week }(\mathrm{g})\end{array}$ & $\begin{array}{c}209.40 \pm \\
11.32\end{array}$ & $212.50 \pm 5.64$ & $210.20 \pm 5.43$ & $215.60 \pm 4.73$ & $219.60 \pm 4.62$ \\
\hline Feed Intake (g) & $575.33 \pm 2.38$ & $594.33 \pm 3.52$ & $603.00 \pm 3.46$ & $632.00 \pm 4.35$ & $636.67 \pm 5.73$ \\
\hline FCR & $2.73 \pm 0.02$ & $2.79 \pm .03$ & $2.87 \pm 0.02$ & $2.89 \pm 0.11$ & $2.91 \pm 0.02$ \\
\hline \multicolumn{6}{|c|}{ Carcass Characteristics } \\
\hline $\begin{array}{l}\text { Dressing } \\
\text { percentage }\end{array}$ & $78.67 \pm 0.90$ & $77.62 \pm 1.10$ & $79.83 \pm 0.96$ & $78.94 \pm 1.34$ & $77.99 \pm 1.05$ \\
\hline $\begin{array}{l}\text { Ready to cook } \\
\text { weight }\end{array}$ & $182.25 \pm 6.80$ & $182.12 \pm 2.98$ & $188.50 \pm 6.61$ & $184.25 \pm 5.49$ & $180.25 \pm 5.45$ \\
\hline
\end{tabular}

This study revealed that the Gliricidia sepium leaf meal included diet up to 1.00 per cent level can safely fed to Japanese Quails without affecting its growth performance and carcass characteristics.

\section{References}

Kout Elkloub, M. Moustafa, E.L., Riry, Shata,
F.H., Mousa, Hana, M.A.M., Alghonimy, A.H. and Yusuf, S.F. (2015). Effect of using Moringa oleifera leaf meal on performance of Japanese quails. Egypt.Poultry Science Journal, 35 (4): 1095-1108.

Mahmud, Muhammad and Shaba, Peter and James, Gana and Wosilat, Abdulsalam. (2015). Growth performance of growing 
quails (Coturnix japonica) fed graded levels of Neem leave meal. international Journal of Applied Research. 1. 4-7.
Snedecor, G.W. and Cochran, W.G. 1990. Statistical methods. 8th Edition, The Iowa State University Press, Ames.

\section{How to cite this article:}

Pasupathi. Karu., C. Valli, S. Gunesekaran, V. S. Mynavathi, M. Manobhavan and Selvan. S. T. 2020. Effect of Graded Dietary Levels of Tree Leaf Meal on Growth Performance and Carcass Characteristics of Japanese Quails. Int.J.Curr.Microbiol.App.Sci. 9(07): 891-893. doi: https://doi.org/10.20546/ijcmas.2020.907.103 